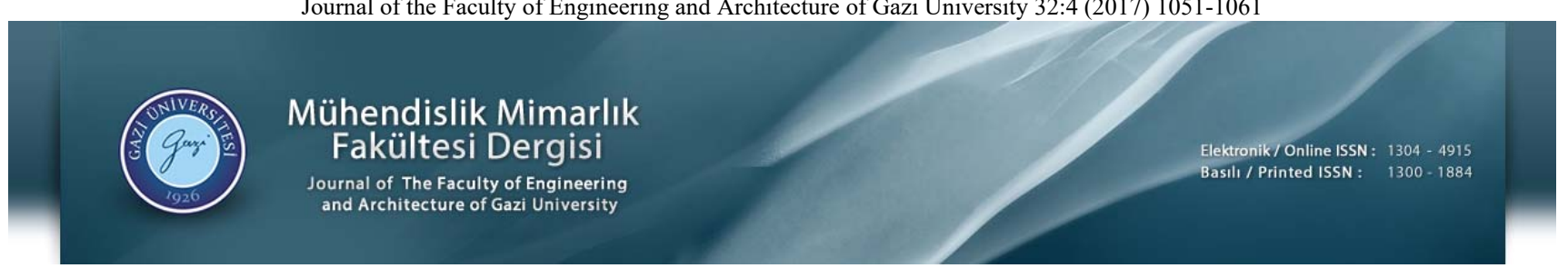

\title{
Nozul içi geometrilerinin partikül erozyonunda hedef malzeme aşınma ve pürüzlülüğüne etkileri
}

\author{
Barış Önen (D) 1*, Sinan Fidan (iD) 1 , Tamer Sınmazçelik (D)2, Ali Çınar (D)3 \\ ${ }^{1}$ Kocaeli Üniversitesi, Havacılık ve Uzay Bilimleri Fakültesi, Kocaeli, 41285, Türkiye \\ ${ }^{2}$ Kocaeli Üniversitesi, Mühendislik Fakültesi Makine Mühendisliği Bölümü, Kocaeli, 41380, Türkiye \\ ${ }^{3}$ Kocaeli Üniversitesi, Teknoloji Fakültesi Otomotiv Mühendisliği Bölümü, Kocaeli, 41380, Türkiye
}

\section{Ö N E Ç I K A N L A R}

- $\quad$ Farklı geometrilerde farklı püskürtme karakteristiğine sahip nozul geometrileri tasarımı

- Farklı nozul geometrilerinin püskürtme ve aşındırma karakterleri

- Farklı nozul geometrileriyle püskürtme sonrası hedef malzemede ortaya çıkan yüzey kalitesi

Makale Bilgileri

Geliş: 24.05.2016

Kabul: 31.07 .2017

DOI:

10.17341/gazimmfd.369362

Anahtar Kelimeler:

Nozul geometrisi,

erozif aşınma,

polymethyl methacrylate

\section{ÖZET}

Bu çalışmada, farklı nozul geometrileri ile aşındırıcı püskürtülmesi sonucu polimetil metakrilat (PMMA) malzemede ortaya çıkan erozif aşınma davranışları karakterize edilmiştir. Erozif aşınmada aşındırııı partikül hızını ve hedef malzemede ortaya çıkan hasar mekanizmasını etkileyen en önemli faktörlerden bir tanesi nozul içi geometrisidir. Endüstride farklı nozul geometrileri, mikro aşındırıcı jet ile işleme ve kumlama gibi birçok farklı uygulamada kullanılmaktadır. Așındırıcı püskürtme; geleneksel aşındırıcıyla malzeme işleme yöntemlerinden bir tanesidir ve mikro aşındırıcı jet ile işleme, yüzey işleme, yüzey temizleme gibi birçok kullanım alanına sahiptir. Bu metotta amaç basınçlı taşıyıcı bir gaz kullanarak aşındırıcı partikülleri nozul içinden geçirerek hızlandırıp hedef malzeme yüzeyine çarptırmaktır. Maksimum aşınma oranı, giriş ve çıkış çapı $5 \mathrm{~mm}$ olan ve tam ortada $4 \mathrm{~mm}$ çaplı boğaza sahip nozulda ortaya çıkarken; minimum aşınma oranı giriş çap $3 \mathrm{~mm}$ çıkış çap $2 \mathrm{~mm}$ olan daralan nozul geometrisinde gözlemlenmiştir. Maksimum ve minimum etki alanı değerleri de; erozyon oranlarının elde edildiği nozullarda gözlemlenmiştir. Maksimum ortalama yüzey pürüzlülüğ̈̈ $3 \mathrm{~mm}$ çaplı sabit kesitli nozulla püskürtme sonrası ortaya çıkarken, minimum ortalama pürüzlülük değeri giriş ve çıkış çapı $5 \mathrm{~mm}$ olan ve tam ortada $3 \mathrm{~mm}$ çaplı boğaza sahip nozulda ortaya çıkmıștır.

\section{Blasting nozzle internal geometry effects on wear and roughness of target material in particle erosion}

\section{H I G H L I G H T S}

- $\quad$ Design of nozzle geometries with different blasting characteristics in different geometries

- Blasting and wear characteristics of different nozzle geometries

- The surface quality of the target material after blasting with different nozzle geometries

\section{Article Info}

Received: 24.05 .2016

Accepted: 31.07 .2017

DOI:

10.17341/gazimmfd.369362

Keywords:

Nozzle geometry,

erosive wear,

polymethyl methacrylate

\begin{abstract}
The aim of this study is to evaluate the effect of nozzle geometry on erosive wear behavior of polymethyl methacrylate (PMMA). One of the most important factors that effects the abrasive particles velocity and damage occurrence in the target material is the internal geometry of the blasting nozzles. Various types of nozzle geometries are used in industry such as abrasive jet micro-machining and sandblasting. Abrasive blasting is a traditional method of abrasive machining process and has a widespread usage area such as micro-machining, surface treatment, surface cleaning. The main purpose of this method is to accelerate the abrasive particles by using a high pressure carrier gas through the nozzle and impacting them to the surface of the target material. Whilst the maximum erosion rate was observed in nozzle with a diameter of $5 \mathrm{~mm}$ in entrance and exit with throat of $4 \mathrm{~mm}$ in mid-point, minimum erosion rate occurred in nozzle with $3 \mathrm{~mm}$ entrance diameter and $2 \mathrm{~mm}$ exit diameter. The maximum and minimum effect area surfaces were observed with the same nozzle geometries. Maximum average surface roughness value measured in samples blasted with constant cross-section $3 \mathrm{~mm}$ diameter nozzles whilst the average roughness was observed in nozzle with a diameter of $5 \mathrm{~mm}$ in entrance and exit with throat of $3 \mathrm{~mm}$ in mid-point.was increased, the lift force was decreased. Thrust force of airfoils made of nylon sheet and latex airfoils are better than those of wood airfoils is found.
\end{abstract}




\section{GÍRIŞ̧ (INTRODUCTION)}

Aşınma, servis süresi boyunca malzemelerin performansını belirleyen önemli parametrelerden biridir [1]. Aşınma genel olarak malzemenin yüzeyinde izafi bir hareket ve mekanik bir etki ile meydana gelen malzeme kaybıdır [2]. Bir sıvı ya da gaz akımı tarafindan taşınan farklı geometrik boyut ve yapıdaki taneciklerin, temasta bulundukları katı yüzeylerinde tekrarlı darbe etkisi yaparak oluşturdukları hasar erozyon aşınması olarak tariflenmektedir. Katı partikül erozyonunda, malzeme yüzeyine belirli bir hizla hareket eden sert partiküllerin çarpması sonucunda yüzeyde malzeme kaybı gerçekleşir. Çeşitli mühendislik uygulamalarında katı partikül erozyonu nedeniyle malzeme kayıpları gerçekleşmektedir [3]. Uzay ve havacılık uygulamalarında, enerji dönüşüm sistemlerinde, jet motorlarında, helikopter rotor kanatlarında, türbinlerde ve kömür dönüştürme santrallerinde vb. bu aşınma tipini yoğun olarak görmek mümkündür. Aşındırıcı partiküller hareketli kanatlara, valf deliklerine, boru bağlantılarına, boru dirseklerine ve diğer yüzeylere çarparak şiddetli malzeme kayıpları meydana getirmektedir [4]. Diğer tribolojik süreçlerde olduğu gibi katı partikül erozyonu da kompleks bir süreçtir. Erozyon mekanizmalarının temel ilkelerinin anlaşılabilmesi için yapılan çalışmalar 20. yüzyılın son yarısında başlamış ve günümüze kadar devam etmiştir. Bütün bu yıllar boyunca bilim adamlarının ilgileri geleneksel malzemelere, özellikle de metallere odaklanmıştır [5]. Katı partikül erozyonu sırasında meydana gelen değişimler birçok faktöre bağlıdır. Aşındırıcı partiküllerin çarpma açısı, hızı, debisi ve boyutu, aşındırıcı partiküllerin karışım oranı, aşınan malzemenin özellikleri, erozyonun meydana geldiği ortamın özellikleri (nem, sıcaklık vb.) katı partikül erozyonunda etkin parametrelerdir [6]. Polimetil metakrilat (PMMA) daha hafif ve kırılmaya karşı dayanımının daha yüksek olmasından dolayı cama alternatif olarak kullanılan şeffaf bir termoplastiktir. Yüksek şeffaflı̆̆ sayesinde otomobil farlarının lenslerinde, denizaltıların gözlem pencerelerinde, uçakların yolcu kabini ve kokpit camlarında günümüzde yaygın olarak kullanılmaktadır. Özellikle kokpit camlarında kullanıldığında yüksek hızda aşındırıcı partiküllerin çarpmasına maruz kalarak mekanik ve şeffaflık özelliklerini kaybedebilmektedirler. Şeffaflığın kaybolması sonrası görüntü geçirgenliğinin düşmesi uçuş emniyetini riske atan bir faktördür [7].

Erozif aşınma, aşındırıcı partiküllerin tekrarlı darbesiyle hedef malzeme hasar bölgesinde ortaya çıkan ve mikromekanik deformasyon/kırılma süreçleriyle hedef malzemede kütle kaybına sebep olan bir süreçtir [8]. Polimerik malzemelerin erozif aşınma oranlarını etkileyen en önemli faktörler dört başlık altında toplanabilir.

1. Hedef malzemelerin özellikleri (malzeme özellikleri ve morfolojisi vs.) [9].

2. Çevre ve test koşulları (sıcaklık, aşındırıcı ile hedef malzeme arasındaki kimyasal etkileşim) [10].
3. Test parametreleri (çarpma açısı, çarpma hızı, akışın debisi, birim zamanda çarpan kütle miktarı vs.) [11].

4. Aşındırıcı partiküllerin özellikleri (boyut, şekil, tip, sertlik vs.) [8].

Herhangi bir polimerin erozif aşınma davranışını değerlendirmek, yukarıda sayılan pek çok parametrenin farklı kombinasyonlarla değerlendirilmesi anlamına geldiği için çok kolay değildir.

Erozif aşınmayı etkileyen en önemli faktörlerden bir tanesi de nozul geometrisidir [12]. Nozul geometrisi aşındırıcı hızını, akış debisini, kesit içindeki partiküllerin yönlenmelerini etkileyerek aşındırıcı partiküllerin hedef malzemedeki hasar mekanizmalarını ve kütle kaybını değiştirebilmektedir. PMMA malzeme partikül erozyonuna maruz kalma riski olan, gerçek bir uygulamayı simüle etmek üzere çalışılabilen ve şeffaf olması nedeniyle erozif aşınma davranışının net takip edilebildiği bir malzemedir. Kantitatif olmamakla birlikte göz ile yapılan inceleme sonrası malzemenin arkasında kalan bölgeye ait görüntü kaybının değerlendirilmesi partikül erozyonu adına bir sonuç verebilmektedir. $\mathrm{Bu}$ avantajları nedeniyle nozul geometrisinin etkilerini ortaya koymak amaciyla 15 farklı iç geometriye sahip püskürtme nozulu imal edilmiş ve deneysel çalışmalarda PMMA malzemesi hedef malzeme olarak kullanılmıştır. Nozul geometrileri seçilirken endüstride mikro-işleme, kumlama ile temizleme, yüzey hazırlama, soğuk sprey kaplama gibi uygulamalarda kullanılma potansiyeli olan nozul geometrileri arasından seçim yapılmıştır. Böylece, deneysel sonuçlardan elde edilen bulgular değerlendirilerek nozul geometrisinin partikül erozyonuna etkilerinin yanı sıra bununla bağlantılı olan endüstriyel uygulamalar için hangi tip nozul geometrisinin uygun olabileceği değerlendirilmiştir.

Aşınma üzerine yapılan çalışmalar incelendiğinde birçoğunun eroziv aşınma dışında aşınma türlerine yönelik çalışmalar olduğu tespit edilmiştir. Titanyum ve nikel alaşımlarına yönelik gerçekleştirilen çalışmada, elektro erozyon parametrelerinin malzeme kaldırma etkileri üzerine deneyler gerçekleş̧irilmiş̧ir [13]. Bir başka çalışmada $\mathrm{Cu}-$ Ni-Mo alaşımlı küresel grafittli dökme demirin aşınma davranışı üzerine matris yapısının ve borlama süresinin etkileri irdelenmiştir [14]. Diğer bir çalışmada, Nikel esaslı bir malzeme olan Waspaloy süper alaşımının tel erozyon yöntemi ile işlenmesinde (WEDM) kesme parametrelerinin ortalama yüzey pürüzlülüğü üzerindeki etkileri araştırılmış ve en düşük yüzey pürüzlülük değerlerini veren en uygun kesme parametreleri belirlenmiştir [15]. Elektro erozyonla ilgili bir çalışmada, DIN 1,2379 kalıp çeliğine, tek delikli pirinç elektrotla, içerisinde farklı miktarlarda oksijen çözünmüss soğutma sıvısı kullanılarak elektro erozyon ile delik delme (EEDD) işlemi uygulanmıştır [16]. Elektro erozyonla ilgili bir başka çalışmada, $\mathrm{Cu}-\mathrm{Cr}$ toz metal (T/M) elektrot kullanımının elektro erozyon ile işleme (EEI) performans çıktılarından iş parçası işleme hızı (ïH), elektrot aşınma hızı (EAH), işlenmiş yüzeyin ortalama ve azami 
yüzey pürüzlülükleri (Ra ve Rz) ve iş parçası yüzey katman kalınlıklarına etkileri deneysel olarak incelenmiştir [17]. Metal dışında, termoplastik polimerlerle ilgili çalışmada ise katkısız poliamid 6 (PA 6) termoplastik polimeri ile katı yağlayıcı vaks katkılı poliamid 6 karışımının, kuru kayma şartları altında kendi üzerlerindeki tribolojik performansları incelenmiştir [18]. Görüldüğü üzere, tribolojik aşınma çalışmalarında eroziv aşınma ve özellikle etkin bir parametre olan nozul geometrilerine bağlı aşınma hasarları üzerine bilgi birikimine ihtiyaç vardır. Bu yüzden yapılan çalışmada erozyon aşınması üzerine yoğunlaşılmıştır. Katı partikül erozyonu sonucu ortaya çıkan yüzey hasarları farklı yüzey inceleme yöntemleri kullanılarak analiz edilebilir. Kullanılan en güvenilir yüzey analizi yöntemlerinden bir tanesi temassız lazer profilometre ile yüzey pürüzlülüğü ölçümleri ve erozyon krateri derinlik profillerinin iki ve üç boyutlu elde edilmesidir [19]. Aşındırıcı partiküllerin kinetik enerjisini etkileyen başlica faktörlerden birisi nozul geometrisidir. $\mathrm{Bu}$ yüzden, ortalama yüzey pürüzlülük değerleri nozul geometrilerindeki değişimleri ifade eden önemli parametrelerden biridir. Hasar analizinde önemli bir başka nokta partikül erozyonu neticesi oluşan kraterin geometrisi ve derinliğidir. Oluşan kratere ait çok hassas ölçümler ve yine temassız lazer profilometre kullanılarak elde yapılabilmektedir. Bu bilgiler 1şığında, 15 farklı tip nozul geometrisiyle gerçekleştirilen erozif aşınma testleri sonrasi hedef malzeme PMMA numunelerde oluşan ortalama yüzey pürüzlülükleri ve krater geometrileri temassız lazer profilometre kullanılarak ortaya konmuştur. Erozif aşınma testleri sonrası yüzey hasarlarını makro düzeyde yüksek çözünürlüklü olarak ortaya koymak amacıyla, yenilikçi bir yöntem kullanılarak; tarayıcı bir sistem ve özel görüntü işleme algoritmalarıyla oluşturulmuş programlar yardımıyla yüzey topografya görüntüleri elde edilmiştir. $\mathrm{Bu}$ amaçla test edilen PMMA numunelerin yüzeyleri tarayıcıda taranıp açık kodlu bir program olan Image-J yardımıyla yüzey topoğrafyaları oluşturulmuştur. Böylece makro düzeyde erozyon krateri yayılım alanları hesaplanabilmiştir.

\section{DENEYSEL METOT (EXPERIMENTAL METHOD)}

\subsection{Malzeme ve Hazırlama Teknikleri \\ (Material and Preparation Techniques)}

Ticari ismi Altuglas CN olan PMMA plakalar test malzemesi olarak seçilmiştir. 4 mm kalınlığında ve $200 \mathrm{~mm}$ x $200 \mathrm{~mm}$ ölçülerindeki şeklindeki PMMA malzemeden $40 \times 40 \mathrm{~mm}$ yüzey alanı olan kareler şeklinde, $4 \mathrm{~mm}$ kalınlıkta numuneler kesilerek hazırlanmışlardır.

\subsection{Erozif Așınma Test Düzeneği \\ (Solid Particle Erosion Test Rig)}

$\mathrm{Bu}$ çalışmada gerçekleştirilen erozif aşınma testleri ASTM G76-95 standardına göre gerçekleştirilmiştir. Aşındırıcı partikül olarak 125-300 $\mu \mathrm{m}$ (80 mesh) boyutlarında köşeli garnet kullanılmıştır. Testler özel tasarlanmış test kabininde $90^{\circ}$ çarpma açısında 1,5 Bar püskürtme basıncında gerçekleştirilmiştir. Aşındırıcı partiküller vakumlu kaptan basınçlı hava yardımıyla çekilerek nozuldan püskürtülmüştür. PMMA numuneler nozul çıkışından 50 mm mesafeye yerleştirilmiştir.

Her numune için 20 saniye süre ile püskürtme yapılmıştır. Her bir parametre için 6 tekrar yapılarak sonuçların ortalaması alınmıştır. Sonuçlar \%96,25 güvenilirlikle ve $\% 3,75$ standart sapma ile verilmiştir. Her numune test öncesi ve sonrası basınçlı hava ile temizlenerek testler sonrası hassasiyeti $\pm 0,1 \mathrm{mg}$ olan hassas terazi ile kütle kayıları ölçülmüştür. Erozif aşınma testlerinde kullanılan düzenek Şekil 1'de gösterilmiştir. Nemi alınmış basınçlı hava ile püskürtülen aşındırıcı parçacıklar Şekil 1'de gösterilen düzenekte $\left(15^{\circ}-90^{\circ}\right)$ açıları arasında hedef malzemeye çarptırılabilmektedir. 15 farklı tip iç geometriye sahip nozul ile yapılan testlerde nozul çıkışı-hedef malzeme arası mesafe $50 \mathrm{~mm}$ olarak sabit tutulup nozul geometrisinin erozif aşınmaya etkileri incelenmiştir. Nozul ölçüleri ve nozul iç geometrileri Şekil 2'de verilmiştir.

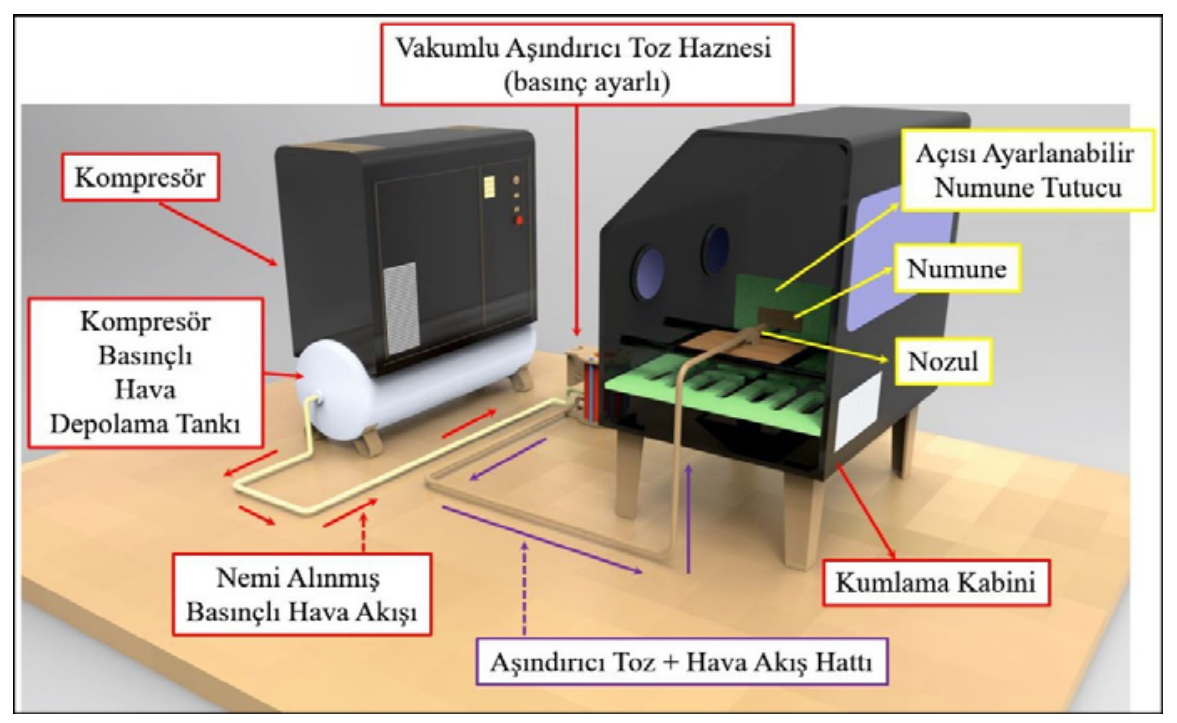

Şekil 1. Erozif aşınma test düzeneği (Solid particle erosion test rig) 


\subsection{Temassız Lazer Profilometre ile Pürüzlülük Ölçümleri} (Laser Profilometer Roughness Measurements)

Erozif aşınma testleri sonrası PMMA numunelerin yüzey pürüzlülük ölçümleri Nanovea PS50 temassız profilometre kullanılarak gerçekleştirilmiştir.
Erozif aşınma testleri sonrası yüzey pürüzlülük ölçümlerinde nozul püskürtme yönüne dik olacak şekilde erozyon kraterinin tam ortasından geçen eksen boyunca ölçüm gerçekleştirilmiştir. Pürüzlülük ölçümlerinde $0,1 \mu \mathrm{m}$ hassasiyetle ölçümün yapıldığı 25 mm'lik çizgi Şekil 3'te görülmektedir.

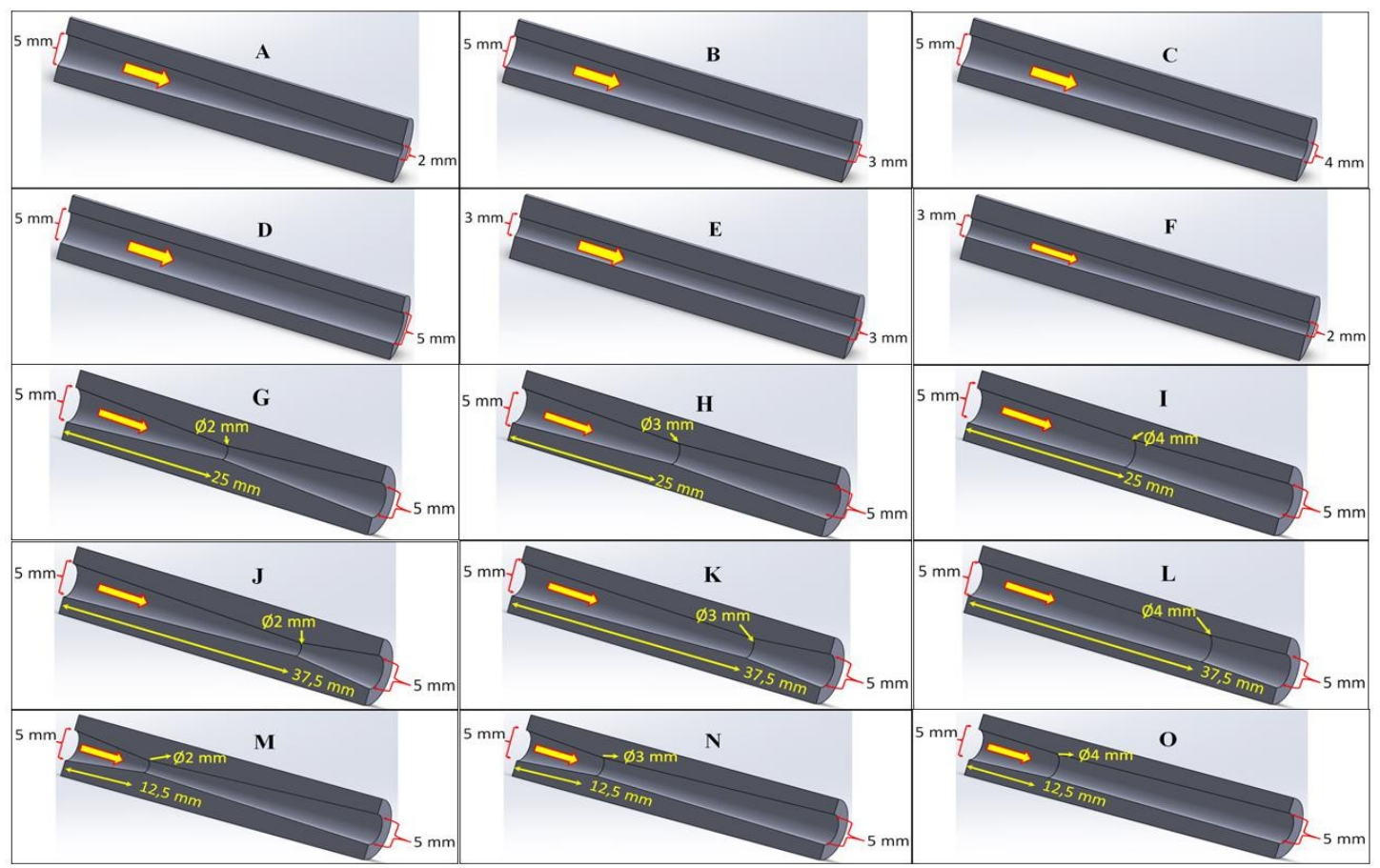

Şekil 2. Erozif aşınma testlerinde kullanılan nozul geometrileri (Nozzle geometries used in solid particle erosion tests)

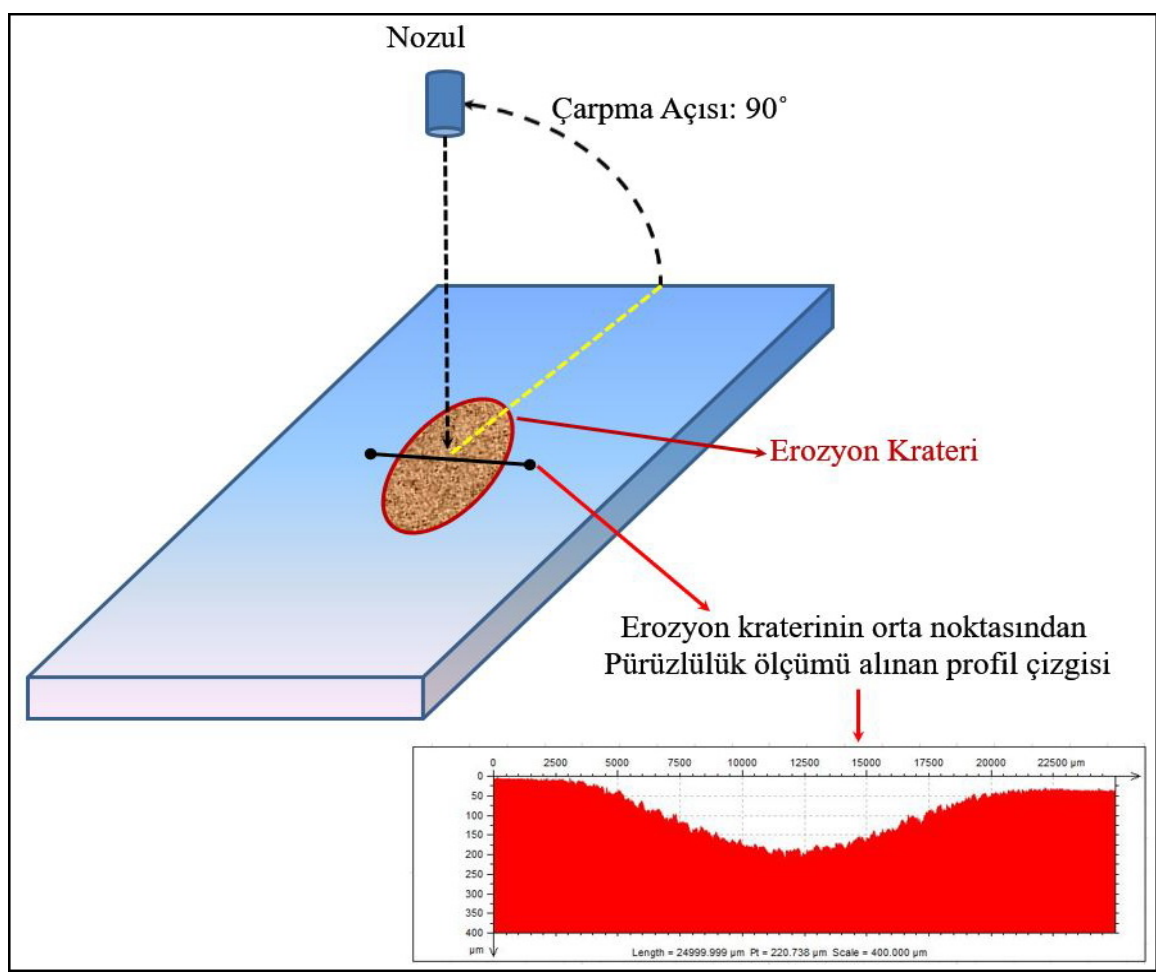

Şekil 3. Yüzey pürüzlülük ölçümü yapılan profil çizgisinin şematik gösterimi (Schematic view of profile line used in surface roughness measurement) 
2.4. Görüntü Işleme ile Yüzey Incelemesi

(Surface Analysis by Image Processing)

Son yıllarda yapılan akademik çalışmalarda masaüstü tarayıcılar; yüksek çözünürlükte görüntü alma özellikleri, objektif ölçüm sonuçları, sonuçların değişkenliklerinin az olması, düşük maliyetleri ve harici 1şık kaynağına ihtiyaç duymamalarından dolayı yaygin olarak kullanılmaktadırlar [20]. Erozif aşınma testleri sonrası PMMA numune yüzeylerinde oluşan hasar, özel kurgulanan bir teknik yardımıyla incelenmiştir. $\mathrm{Bu}$ özel yöntemle, PMMA test numunelerinin yüzeylerindeki erozif aşınma hasarı yayılım alanı hesaplanarak değerlendirilmiştir. PMMA numune yüzeylerinin görüntüleri HP Scanjet G2710 yatay tarayıcı ile elde edilmiştir. Tarayıcı bileşen olarak cam bir tarama zemini, üzerini örten 1 ş1k geçirmez opak bir kapak, bir aydınlatma kaynağı, CCD sensörler ve görüntü işlemede kullanılan bir yazılımdan oluşur. Taranacak hasarlı numune yüzeyi cam zemin üzerine yerleştirilerek dişardan ortam ışı̆̆ının girmesini engelleyen opak kapak kapatılarak taramalar gerçekleştirilmiştir. Tarayıcı içindeki CCD sensör ve 1 şık kaynağı yüzey boyunca hareket ederek görüntü bilgilerini toplamıştır. Elde edilen görüntüler açık kodlu bir program olarak kullanılan Image J programı kullanılarak işlenmiştir. Programla görüntü işleme sürecinden sonra erozif aşınma hasarı oluşan PMMA numunelerin yüzeyindeki hasar dağılım bölgeleri görüntüleri elde edilmiştir. Görüntü işleme ile yüzey incelemede kullanılan işlem basamakları Şekil 4'te verilmiştir.
2.5 Çift Disk Metodu ile Aşındırıcı Partikül Hız Ölçümleri (Abresive Particle Velocity Mesurements by Double Disc Method)

Farklı nozul geometrilerinde, nozul çıkışından sonra aşındırıcı partiküllerin hedef malzeme üzerine çarparken sahip oldukları hızları ölçmek amacıyla litertürde temel ölçüm metotlarından biri olan çift disk metodu kullanılmıştır. Literatürde belirtildiği şsekilde oluşturulan ölçüm düzeneği yardımıyla metodoloji gerçekleştirilmiştir. $[21,22]$. Ölçülen partikül hızları Şekil 5 'te verilmiştir.

\section{SONUÇLAR VE TARTIŞMALAR (RESULTS AND DISCUSSIONS)}

PMMA numunelerin erozif aşınma testleri 15 farklı nozul geometrisi kullanılarak gerçekleştirilmiş ve ortaya çıkan kütle kayıplarının ve erozyon oranlarının nozul geometrilerine göre değişimi Şekil 6'daki grafikte verilmiştir. Nozullar ölçülerine ve iç geometrilerine göre 4 gruba ayrılarak sonuçlar karşılaştırılmıştır. Tüm nozul geometrileri içinde maksimum kütle kaybı grup 2'de bulunan "I" nozulunda ortaya çıkmıştır. Bu nozulun boğazı nozul boyunun tam orta noktasında ve $4 \mathrm{~mm}$ çapa sahiptir. Giriş ve çıkış çapı $5 \mathrm{~mm}$ olan bu nozulun boğazının tam ortada ve $4 \mathrm{~mm}$ çapta olması maksimum aşındırıcı partikül püskürtme hızına ulaşmayı sağlamış, bu hız hedef malzeme olan PMMA yüzeyine maksimum kinetik enerjiyle çarpan garnet partiküllerinin maksimum kütle kaybına uğramasına sebep olmuştur.

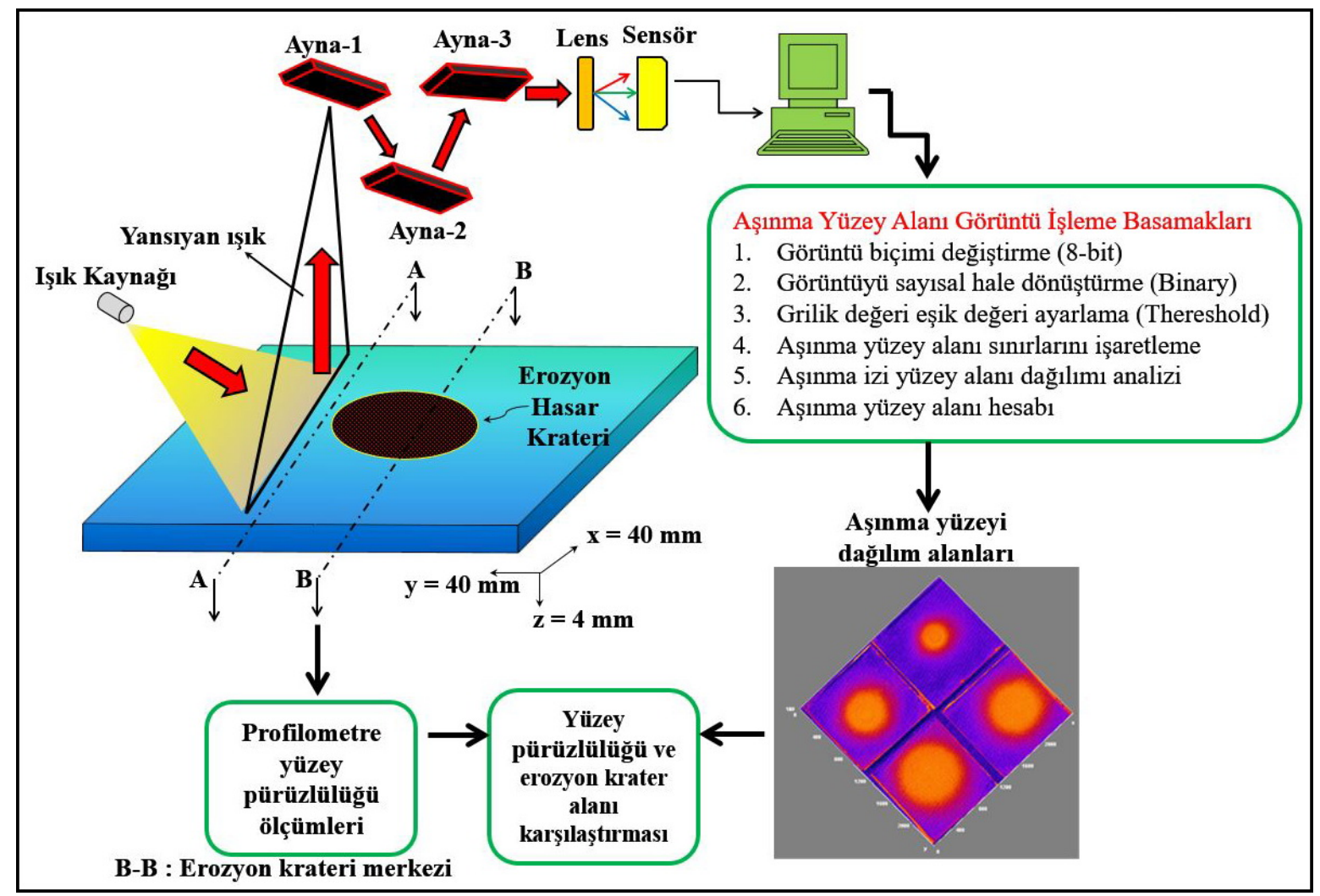

Şekil 4. Görüntü işleme ile yüzey hasar bölgesi dağılımı analiz basamakları (Analysis steps of surface damage area distribution image processing) 


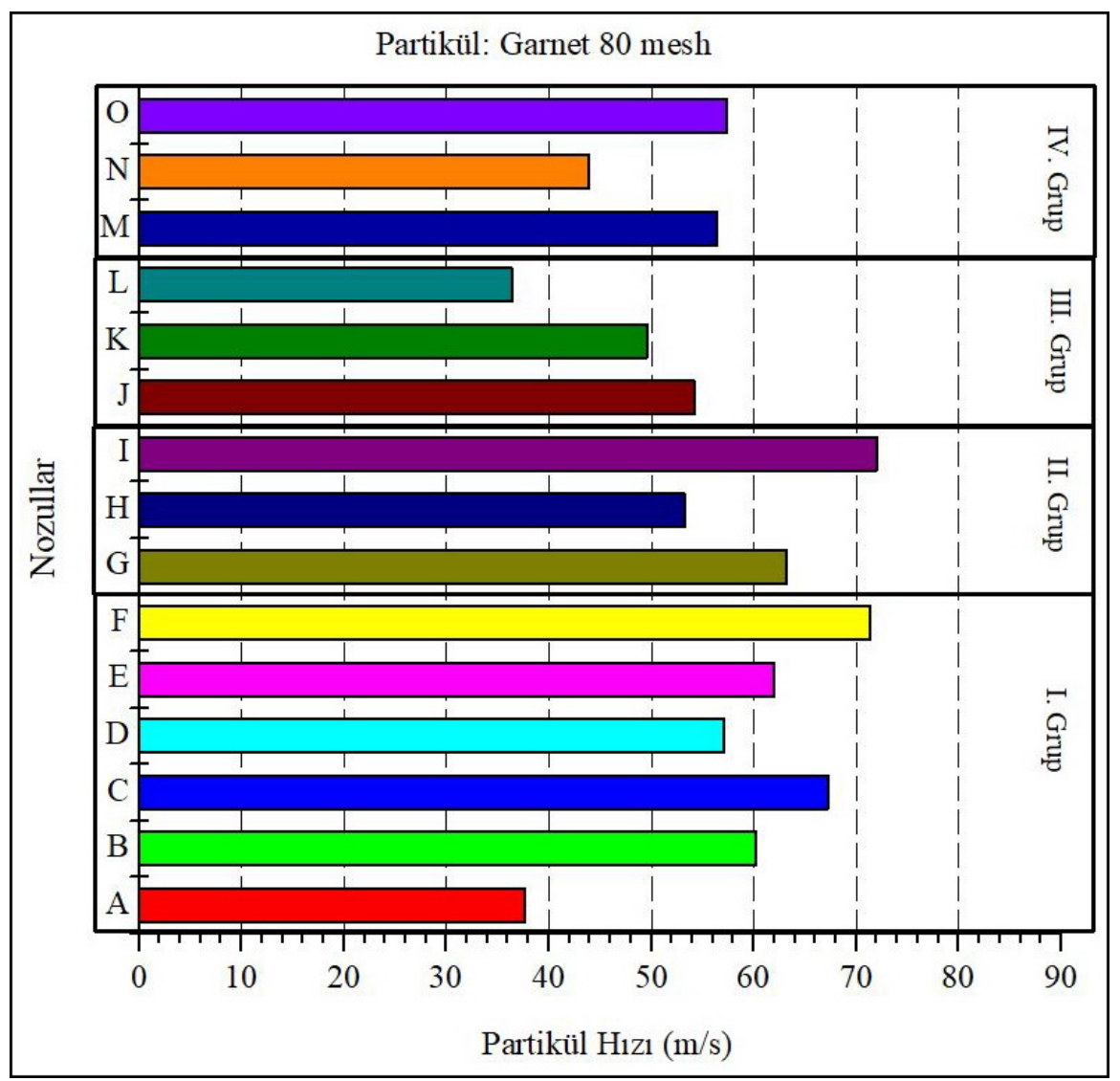

Şekil 5. Farklı nozul geometrilerinden püskürtülen Garnet'in ( 80 mesh) çift disk metodu ile ölçülen hızları (Velocity measurment of Garnet blasted from various nozzle geometries by using double disc method)

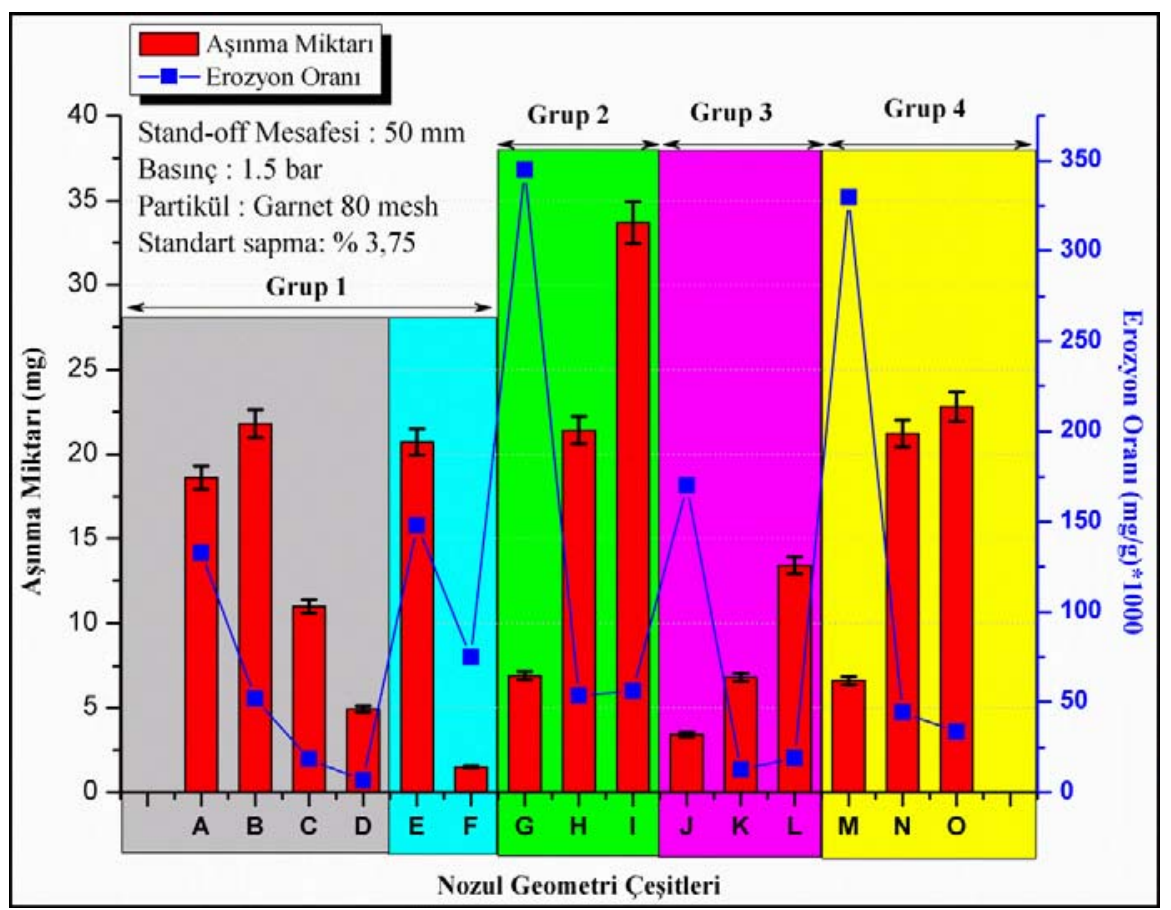

Şekil 6. Farklı nozul geometrilerinde ortaya çıkan kütle kayıpları ve erozyon oranları (Mass loss and erosion rates occured with various nozzle geometries) 
Sonuç olarak yüzeyde derinlemesine temizleme işlemi yapılması gereken uygulamalarda bu tip nozul geometrisinin kullanılması kumlama verimliliğini artıracaktır. Erozyon oranı; hedef malzemede ortaya çıkan kütle kaybının, püskürtme süresi boyunca hedef malzemeye çarpan toplam aşındırıcı kütlesine bölünmesiyle elde edilir. Minimum erozyon oranı giriş ve çıkış çap1 $5 \mathrm{~mm}$ olan D nozulunda ortaya çıkarken; maksimum erozyon oranı nozul giriş ve çıkışı $5 \mathrm{~mm}$ olan, tam ortada $2 \mathrm{~mm}$ 'lik boğaza sahip G nozulunda ortaya çıkmıştır. Yapılan çalışmada nozul geometrilerinin hedef malzeme üzerindeki aşındırma ve kütle kaybına etkilerine odaklanılmış olduğundan değerlendirmeler bu yönde yoğunlaştırılmıştır. Diğer taraftan kütle kaybının fazla olması nedeniyle, hedef malzemenin temizleme sonrası servis şartlarındaki çalışma toleranslarının içinde kaldığından emin olunmalıdır. Hedef malzeme kalınlığındaki erozif aşınmaya bağlı azalma, servis şartları altında malzemenin taşıyacağı yükler açısından sorun teşkil etmemelidir.

Tüm nozul geometrileri içinde hedef malzemede minimum kütle kaybının ortaya çıktığı nozul "F" kodlu "laval tip" nozuldur. Bu nozulda giriş çapı $3 \mathrm{~mm}$, nozul çıkış çap1 ise 2 mm'dir. Bu nozul geometrisinde herhangi bir noktada boğaz bulunmamaktadır. F nozulundan çıkan partiküllerin hızı yüksek olmasına rağmen aşınma miktarının az olması, hedef malzemeye çarpan aşındırıcı partikül sayısının az olmasıdır. Aşınma miktarının az olması bu tip nozulun hassas temizleme ve işleme işlemleri yapılması gereken yüzeylerde kullanımının uygun olacağı sonucunu ortaya koymuştur. Nozul geometrileri gruplandirılarak elde edilen aşınma miktarı sonuçları irdelendiğinde, çıkışa yakın boğaza sahip grup 3 nozul geometrilerinin (J, K ve L nozulları) aşınma testleri sonrası minimum kütle kaybına sebep oldukları görülürken; ortada boğaza sahip grup 2 nozulların (G, H ve I nozulları) yüksek miktarda hedef malzemede kütle kaybına sebep oldukları görülmüştür. Çıkışa yakın boğaza sahip J, K ve $L$ nozullarında aşındırıcı partiküllerin nozul içinde hızlanmasının düşük seviyede kalarak hedef malzeme yüzeyinde düşük kütle kaybına sebep oldukları ortaya konmuştur. Diğer taraftan aşındırıcı partiküllerin hedef malzeme yüzeyine yüksek kinetik enerjiyle çarpmalarına ve çok sayıda partikülün çarpmasına bağlı kütle kayıplarının H ve I nozullarında yüksek seviyede olduğu görülmüştür.

Şekil 7'de farklı nozul geometrileriyle gerçekleştirilen testler sonrası PMMA malzemede gerçekleşen malzeme yüzeyindeki etki alanları karşılaştırması verilmiştir. Hedef malzemelerde ortaya çıkan aşınma etki alanları incelendiğinde en büyük miktarı, tam orta noktada boğaza sahip "I" nozul geometrisinde gözlemlenmiştir. Aşınma miktarları karşılaştırmasında olduğu gibi etki alanı büyüklüğünde de en yüksek değere "I" nozul geometrisi sahip olmuştur. Bu yüzden "I" tipi nozul geometrisi, hem derinlemesine temizlik ve/veya aşındırma istenen ama aynı zamanda bunu büyük etki alanına sahip olarak ekonomik şekilde yapmak hedeflenen uygulamalarda en verimli nozul geometrisi olacaktır. Diğer taraftan en dar etki alanına sahip nozul "F" nozulu olmuştur. "F" nozulu Şekil 6' da gösterilen aşınma miktarları karşılaştırmasında da en az aşınmaya sebep olan nozul tipi olmuştur. Bu iki sonuç birleştirildiğinde hassas yüzey temizleme işlemlerinde hedef malzemede kütle kayıplarına neden olmadan gerçekleştirilecek işlemlerde, giriş çap1 $3 \mathrm{~mm}$ olan laval tip nozul olan "F" tipi nozul en

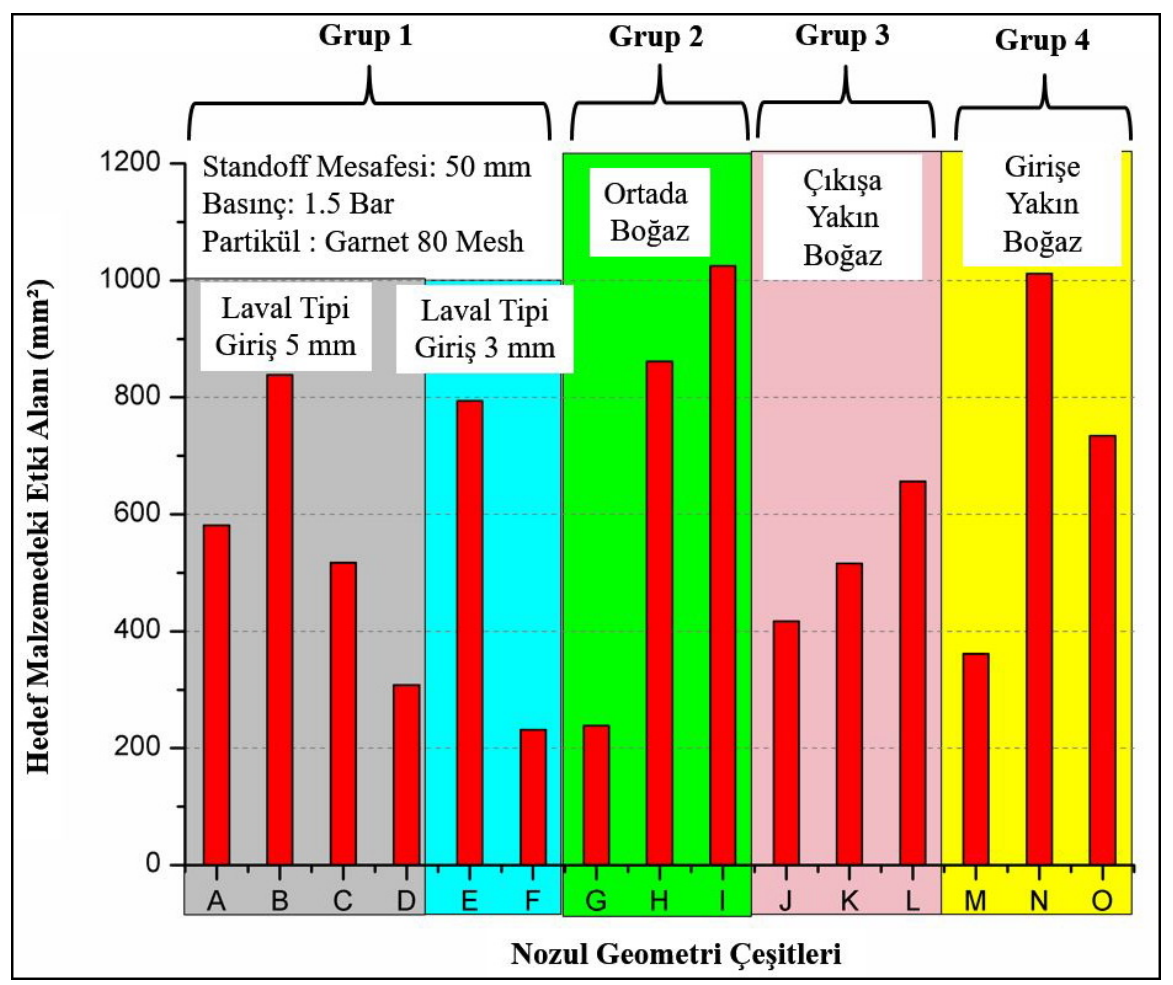

Şekil 7. Farklı nozulların hedef malzeme yüzeyindeki etki alanları (Surface effect area with various nozzle geometries) 
uygun nozul geometrisi olarak gözükmektedir. Mücevher ve değerli taş temizleme, tarihi küçük eserlerin temizlenmesinde temizlenecek malzemenin doğal patinasına zarar vermeden gerçekleştirilmesi gereken restorasyon işlemlerinde bu tip nozulun kullanılmasının uygun olacağ görülmektedir. Şekil 8'de 15 farklı nozul geometrisiyle gerçekleştirilen erozif aşınma testleri sonrası PMMA yüzeylerinde ortaya çıkan hasar bölgelerinin görüntü işleme tekniğiyle elde edilen dağılımları verilmiştir. Görüntü işleme basamakları uygulanmadan önce yüksek çözünürlükte yatay tarayıcıda numunelerin hasarlı bölgelerinin görüntüleri tarama yapılarak elde edilmiştir. Hasar bölgesinin dağılımının net analizi için Image J programında filtre olarak Fire LUT kullanılmıştır. Böylece aşındırıcı partiküllerin

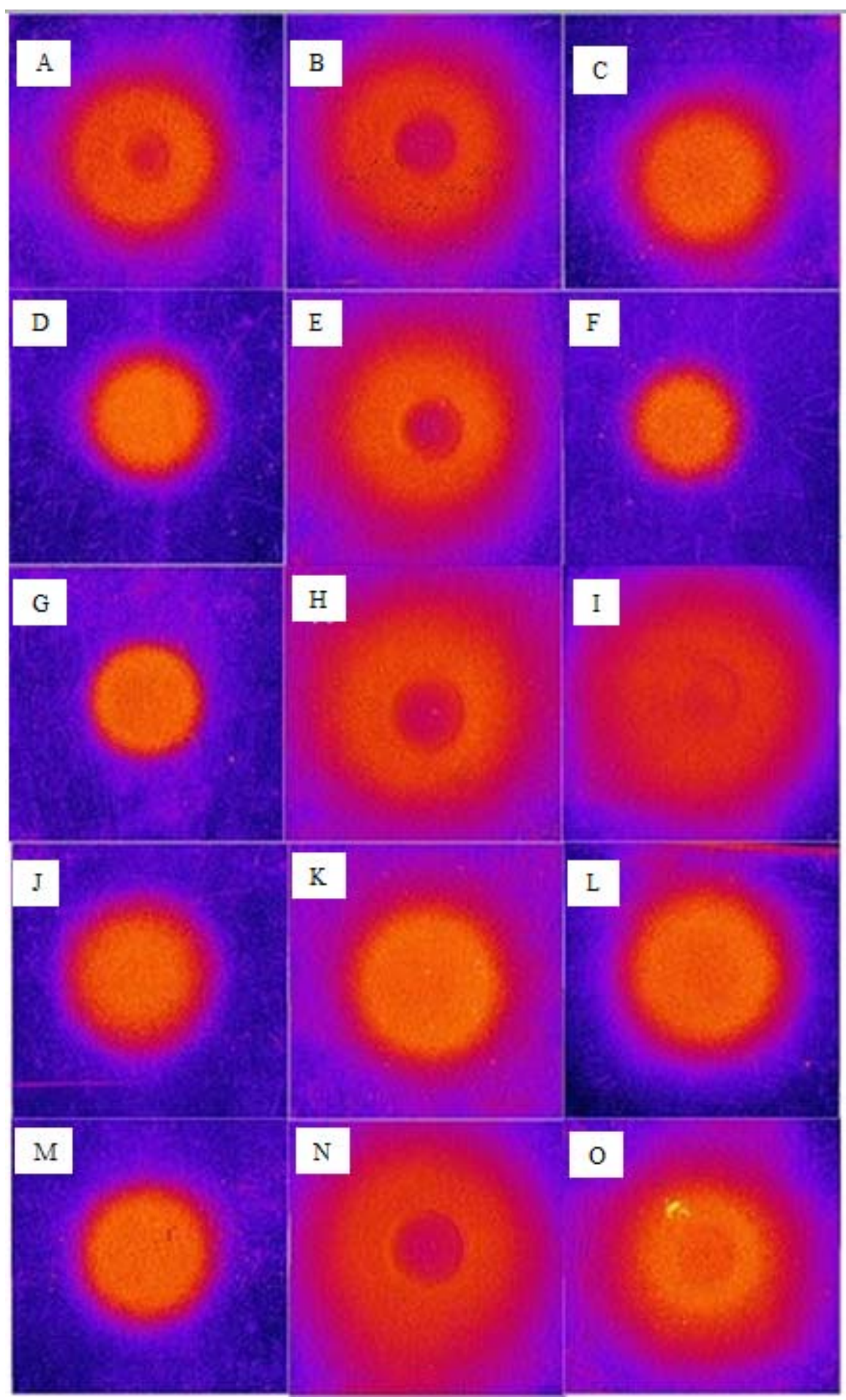

Şekil 8. Farklı nozulların PMMA yüzeylerinde ortaya çıkardığı hasar bölgeleri (Surface damage areas with various nozzles at PMMA surfaces) 
PMMA yüzeyinde oluşturdukları aşınma etkinliği ortaya konabilmiştir. Hiç aşınmaya uğramamış bölgeler mor renkli, az aşınmış bölgeler kırmızı renkli ve en çok aşınmanın olduğu bölgeler turuncu renkli spektrumla görülmektedir. Şekil 8 incelendiğinde "F" ve "G" tipi nozulların en küçük etki alanına sahip oldukları, Şekil 6 ve Şekil 7’deki sonuçları da doğrulayacak şekilde görülmüştür. "G" tipi nozulda aşınmanın daha homojen ve derin olduğu diğer taraftan " $F$ " tipi nozulda halka şeklinde kırmızı renkli az aşınma bölgesinin de oluştuğu gözlemlenmiştir. En geniş etki alanına ise "I", "N" ve "H" tipi nozullarda rastlanmıştır. "A", "B", "E", "H" ve "N" tipi nozullarla püskürtme sonras1 ise yüzeyde orta kısımda daha az aşınma olan bir dairesel bölge oluşurken, dairenin kenarlarında halka şeklinde daha derin aşınmanın oluştuğu bir bölge ortaya çıkmıştır. Nozul geometrisine bağlı olarak bu tip nozullarda orta kısımda aşındırıcı partiküllerin nozul içinde hızlanırken birbirleriyle fazla etkileşime girerek kinetik enerjilerini kaybettikleri ve merkezde daha az aşındırmaya sebep oldukları söylenebilir.

Erozif aşınma testleri sonrası hedef malzemede ortaya çıkan en önemli hasarların başında yüzey pürüzlülük oluşumu ve aşınan yüzeye ait topografya değişimi gelmektedir. Aşındırıcı partiküller hedef malzeme yüzeyine çarptıklarında kinetik enerjileri hedef malzeme tarafından sönümlenerek, hedef malzemeden parça kopmasına bağlı kütle kaybına sebep olabilmektedir. Diğer taraftan aşındırıcı partiküllerin hedef malzemede ortaya çıkardığı bir başka hasar da yüzey pürüzlülüğünde artış ve topografyasında değişimdir. Dövme, ekstrüzyon gibi hasar mekanizmaları yüzeye normal açıda çarpan partiküllerin hedef malzeme yüzeyinde plastik deformasyona bağl1 derin kraterler şeklinde yüzey topografyasının bozulmasına sebep olmaktadır. Tüm bu gerçekler 1şı̆̆ında, erozif aşınma testleri sonrası yüzey pürüzlülük değerlerinin ve topografyasının nasıl değiştiğinin analizinin yapılması önem arz etmektedir. Bu yüzden,
PMMA hedef malzemeyle 15 farklı tip nozul geometrisi kullanılarak yapılan erozif aşınma testleri sonrası yüzey pürüzlülük ve topografya analizi temassız lazer profilometre ile gerçekleştirilerek karşılaştırmalı sonuçlar Şekil 9'da verilmiştir. Erozif aşınma sonrası pürüzlülük taramaları aşınma kraterinin tam orta noktasından alınarak ortaya çıkan kraterin nüfuziyet ve hasar derinliği ortaya konulmaya çalışılmıştır.

Şekil 9'da açık şekilde görüldüğü gibi, diğer test parametreleri sabit tutulup sadece nozulların geometrileri değiştirildiğinde aşındırıcı partiküllerin hedef malzeme yüzeyinde ortaya çıkardıkları krater geometrileri çok farklı olmaktadır. Yüzey topografyasını yüksek miktarda hasara uğratarak yüzeyde derin hasar vadilerinin oluşması "E", "A" ve "I" kodlu nozullarda gözlemlenmiştir. Özellikle "E" ve "A" tipi geometrili nozullarda aşındırıcı partiküllerin nozul içinde hızlanma sonrası birkaç farklı akış bölgesi oluşturarak farklı geometrilerde hasar vadileri oluşturduğu tespit edilmiştir. Nozul içinde farklı akış bölgelerinin oluşması nozul iç geometrileriyle birebir bağlantılıdır. Diğer taraftan "F", "G" ve "J" tipi nozullarda aşındırıcı partiküllerin hedef malzeme PMMA yüzeyine homojene yakın bir dağılımla çarparak yüzey topografyasında çok az değişime sebep oldukları görülmüştür. "A", "B", "H" ve "N" tipi nozullarda tam merkezde yüksek bir tepe şeklinde az hasara uğramış bölge görülürken bu tepenin etrafinda daha derin şekilde hasar vadisinin oluştuğu gözlemlenmiştir. Bunun sebebi bu tip nozullarda nozul içi geometrisine bağlı olarak aşındırıcı partiküllerin hızının merkezde düşerken, halka şeklinde bir akış bölgesinde aşındırıcı partiküllerin hızının çok yükselmesidir. Şekil 10'da PMMA numunelerle gerçekleştirilen erozif aşınma testleri sonrası lazer profilometre ile elde edilen ortalama pürüzlülük değerlerinin (Ra) karşılaştırması verilmiştir. Şekil 10 incelendiğinde " $H$ " ve "I" tipi nozullarda Ra değerinin diğer nozul tipleriyle

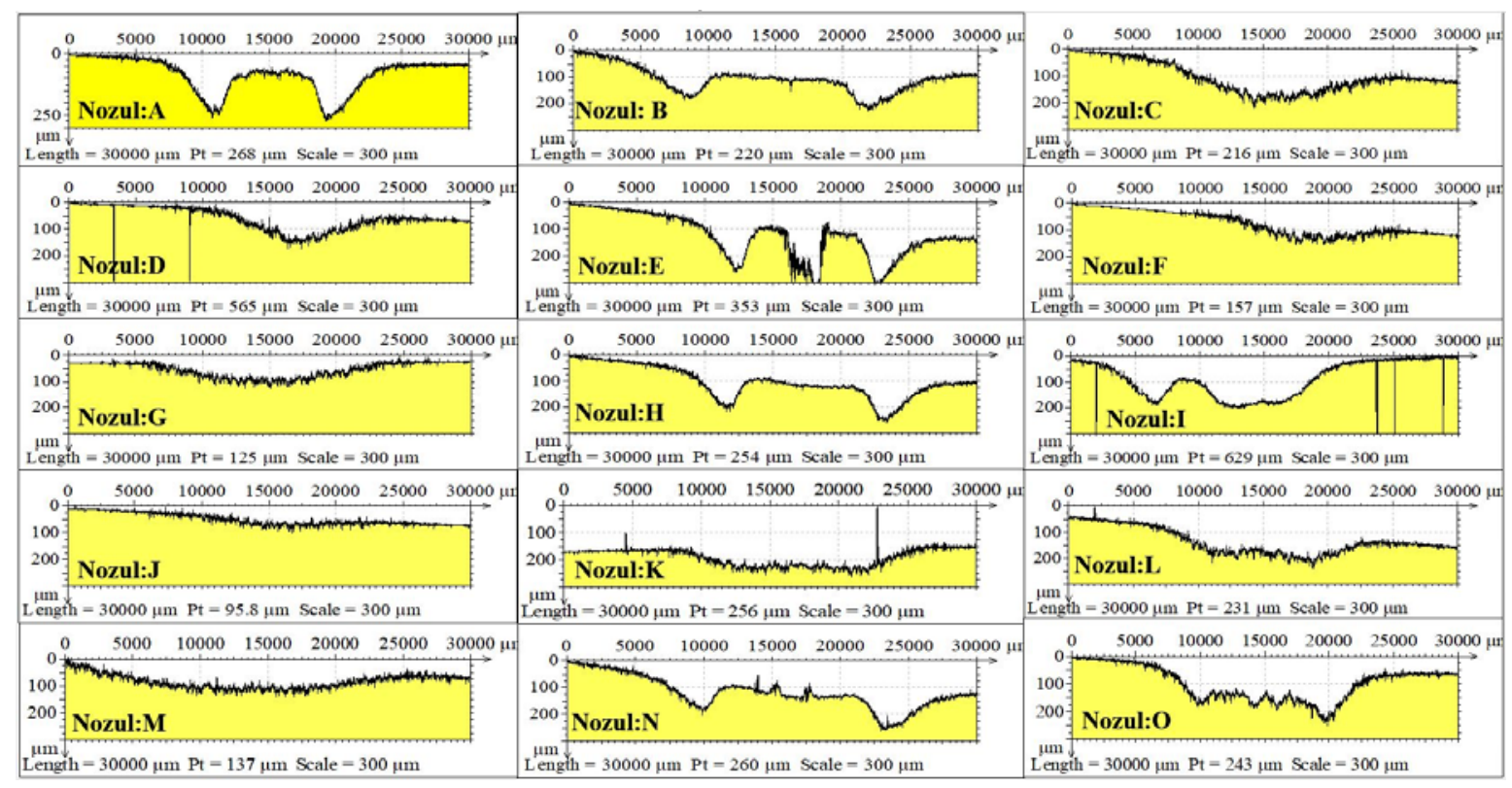

Şekil 9. Hasar kraterinin orta noktasındaki pürüzlülük profillerinin karşılaştırılması (Mid-point erosion crater roughness profile comparisons) 


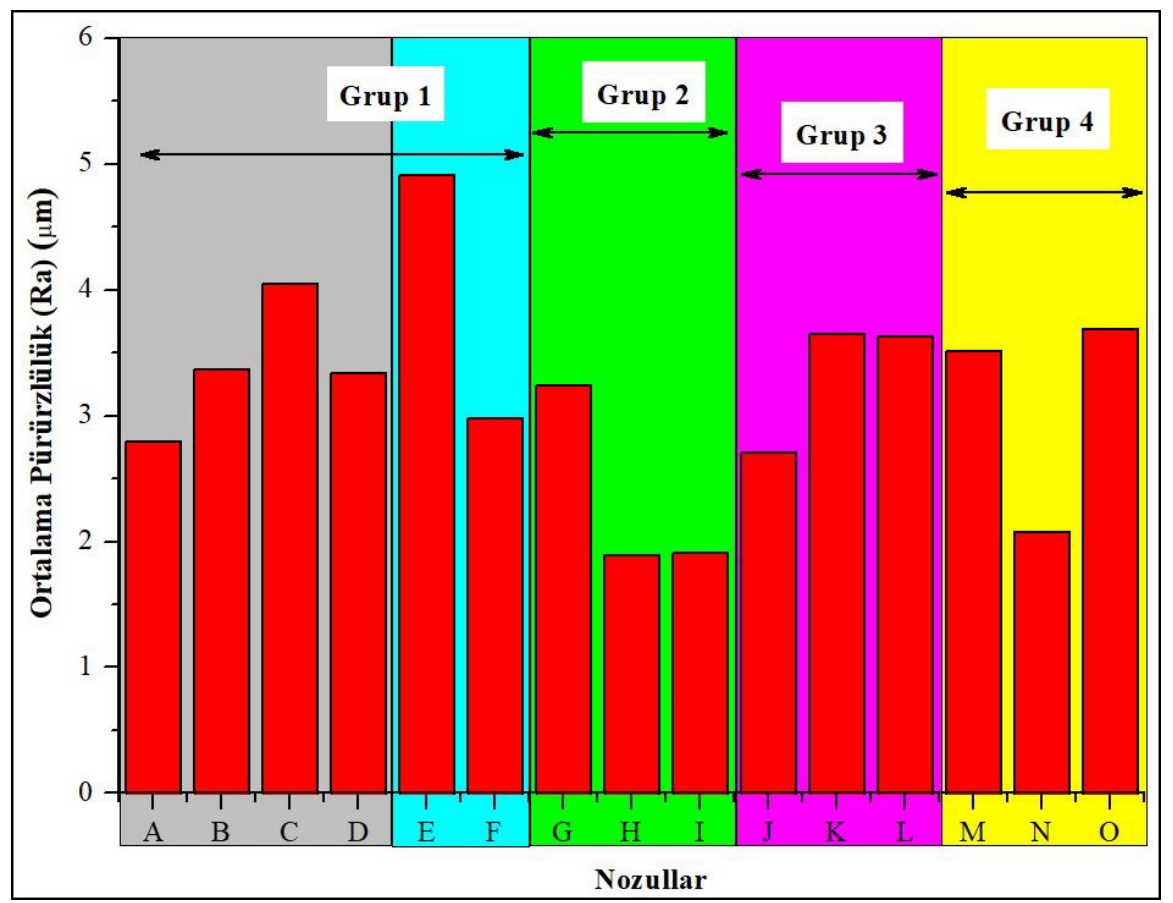

Şekil 10. PMMA yüzeyleri ortalama pürüzlülük değerleri $(\mathrm{Ra})$ karşılaştırması (Average roughness $\left(\mathrm{R}_{\mathrm{a}}\right)$ comparison of PMMA surfaces)

karşılaştırıldığında minimum seviyede oldukları gözlemlenmiştir. Buradan yüzey pürüzlülük değerinin çok artmadan kumlama işlemi yapılması gerektiğinde tam orta noktada daralan boğaza sahip ventüri tip nozulların uygun olduğu görülmektedir. En yüksek yüzey pürüzlülük değeri "E" tipi nozulla püskürtme sonrası malzeme yüzeyinde ortaya çıkmıştır. "E” tipi nozulun Şekil 9'da verilen yüzey topografya kesiti de maksimum pürüzlülük değeri ile örtüşmektedir. Maksimum aşınma miktarı sıralamasında ise "E" tipi nozul en yüksek değere sahip değildir. "E” nozulu çıkışında aşındırıcı partiküllerin etkisi malzeme kalınlık ekseninde çok olmasına rağmen yüzeyde geniş bir alanda yüksek kütle kaybına sebep olmamıştır.

\section{SONUÇLAR (CONCLUSIONS)}

Yapılan çalışmada farklı püskürtme nozul geometrilerinin hedef malzeme üzerindeki etkileri ve farklı nozul geometrilerinin yüzey üzerinde ortaya çıkardığı etkilerle hasarlar ortaya konulmaya çalışılmıştır. Hedef malzeme olarak seçilen PMMA özellikle uçak camlarında alternatif malzeme olarak yeni nesil uçak yapılarında giderek artan oranda kullanılmaya başlanmıştır. Bu durum, hem doğal servis şartları altında havada asılı bulunan katı partiküllerin bu malzemenin yüzeyine çarpması sonucu ortaya çıkabilecek hasarların ve aşınmanın irdelenmesi hem de malzemenin uçak parçası olarak imalatı sırasında kullanılan mikro aşındırıcı jet ile kesme gibi süreçlerde ne tür etkilerinin ortaya çıkabileceğinin tartışılması açısından önemlidir. Bu yüzden farklı nozul geometrilerinin aşındırıcı püskürtme karakteristiğini ortaya koymak amaciyla 15 farklı tip nozul kullanılarak testler gerçekleştirilmiştir. Erozif aşınma testleri sonrası PMMA hedef malzemede en fazla kütle kaybı, tam ortada 4 mm boğaz çapına sahip nozul giriş ve çıkış çapları $5 \mathrm{~mm}$ olan "I" tipi nozulda ortaya çıkmıştır. "I" tipi nozul ayrıca hedef malzeme PMMA yüzeyinde maksimum genişlikte etki alanına sahip olmuştur. Diğer taraftan "I" tipi nozulla yapılan aşınma testleri sonrası yüzeydeki etki alanının geniş olması ve aşındırıcı partiküllerin homojen bir şekilde yüzeye çarpmalarına bağlı olarak ortaya çıkan yüzey pürüzlülük değeri düşük seviyelerde kalmıştır. Gerçekleştirilen erozif aşınma testleri sonrası minimum aşınma miktarı, girişte $3 \mathrm{~mm}$ çapa ve çıkışta $2 \mathrm{~mm}$ çapa sahip "F" tipi nozulda gözlemlenmiştir. $\mathrm{Bu}$ tip geometrinin aşındırıcı partiküllerin hedef malzemeye çarpmadan önce kinetik enerji ve buna bağlı hızlarının düşük seviyede kalmasına sebep olduğu; bu yüzden hedef malzemede kütle kaybına sebep olacak seviyelere ulaşılamadığı tespit edilmiştir. Bununla birlikte " $F$ " tipi nozulla püskürtme sonucu hedef malzeme yüzeyindeki aşındırıcı partiküllerin etki alanının da küçük çaplı bir bölge şeklinde ortaya çıktığı görüntü işleme yöntemiyle tespit edilmiştir. Bu bölgesel etki alanı aynı zamanda hasar kraterinin merkezde ve yüzey topografyasını çok değiştirmeyecek şekilde ortaya çıkmasına sebep olmuştur. Pürüzlülük ölçümlerinde ise bölgesel etki alanına fazla sayıda çarpan aşındırıcı partiküller diğer nozullarla karşılaştırıldığında orta seviyede bir yüzey pürüzlülüğü yaratmıştır.

Yapılan çalışmayla PMMA erozif aşınma davranışında aşındırıcı partikül püskürtmede kullanılan nozulların iç geometrilerinin önemli bir etkiye sahip olduğu ortaya konmuştur. Nozul geometrisi değiştiğinde hedef malzemede ortay çıkan kütle kaybı, aşınma bölgesinin yüzeyde dağılımı, yüzey topografyası ve yüzey pürüzlülük değeri gibi birçok 
parametre değişmektedir. Her nozul geometrisi, aşındırıcı partiküllerin nozul içinde hızlandırılırken farklı akış karakteristiği kazanmasına sebep olmaktadır. Bununla birlikte, nozul çıkışında nozul geometrisine bağlı olarak aşındırıcı partiküllerin hedef malzeme yüzeyine ulaşana kadar farklı şekilde birbirleriyle etkileşime girdikleri sonucuna varılmıştır. Bunun kanıtı olarak hedef malzeme yüzeyinde ortaya çıkan topografya geometrisi ve pürüzlülük dağılımı görüntülenmiştir. Diğer taraftan görüntü işleme ve profilometre ile pürüzlülük ölçümü gibi gelişen inceleme yöntemleri, erozif aşınma sonrası hedef malzemelerde ortaya çıkan hasar mekanizmalarının değerlendirilmesinde derinlemesine analiz imkanını artırmaktadır. Gelecekteki çalışmalarda daha farklı geometride nozullar üretilerek yeni çalışmalar yapılması bu alandaki bilgi birikimine katkı sunacaktır.

\section{TEŞEKKÜR (ACKNOWLEDGEMENT)}

Bu çalışmada, erozif aşınma testleri Kocaeli Üniversitesi Havacılık ve Uzay Bilimleri Fakültesi Aşınma Laboratuvarında gerçekleştirilmiştir. $\mathrm{Bu}$ yayının farklı aşındırıcı boyutlarıyla gerçekleştirilen ön çalışması 24-26 Haziran 2015 tarihinde Skiathos, Yunanistan'da gerçekleştirilen 4th International Conference of Engineering Against Failure konferansinda 'The Effect of Nozzle Geometry on Erosive Wear of Polymethyl Methacrylate' başlıklı poster sunumla sunulmuştur.

\section{KAYNAKLAR (REFERENCES)}

1. Rana F. and Stefanescu D.M., Friction properties of Al1.5 Pct $\mathrm{Mg} / \mathrm{Sic}$ particulate metal-matrix composites, Metall. Trans. A, 20 (8), 1564-1566,1989.

2. Deuis R.L.L., Subramanian C., Yellup J.M.M., Abrasive wear of aluminium composites-A review, Wear, 201 (12), 132-144, 1996.

3. Sundararajan G. and Roy M., Solid particle erosion behaviour of metallic materials at room and elevated temperatures, Tribol. Int., 30 (5), 339-359, 1997.

4. Bağc1 M., İmrek H., CuZn10 ve CuSn10 bakır alaşımlarının erozif aşınması, 5. Uluslararası İleri Teknolojiler Sempozyumu (IATS'09), Karabük, Türkiye, 1-5, 13-15 Mayıs.2009.

5. Finnie I., Some reflections on the past and future of erosion, Wear, 186-187 (1), 1-10,1995.

6. Veinthal R., Tarbe R., Kulu P., Käerdi H., Abrasive erosive wear of powder steels and cermets, Wear, 267 (11), 1838-1844, 2009.

7. Fidan S., The evaluation of solid particle erosion in polymethyl methacrylate by surface topography mapping, Acta Phys. Pol. A, 125 (2), 494-496, 2014.

8. Sinmazçelik T., Fidan S., Günay V., Residual mechanical properties of carbon/polyphenylenesulphide composites after solid particle erosion, Mater. Des., 29, 1419-1426, 2008.
9. Pei X. and Friedrich K., Erosive wear properties of unidirectional carbon fiber reinforced PEEK composites, Tribol. Int., 55, 135-140, 2012.

10. Zhao G., Hussainova I., Antonov M., Wang Q., Wang T., Yung D.L., Effect of temperature on sliding and erosive wear of fiber reinforced polyimide hybrids, Tribol. Int., 82 (PB), 525-533, 2015.

11. Abedini M. and Ghasemi H. M., Synergistic erosioncorrosion behavior of Al- Brass alloy at various impingement angles, Wear, 319 (1-2), 49-55, 2014.

12. Stevenson A.N.J. and Hutchings I.M., Scaling laws for particle velocity in the gas-blast erosion test, Wear, 181183 (PART 1), 56-62, 1995.

13. Göv K., Experimental investigation of the effects of the coolant on the performance parameters of electrical discharge drilling of some aerospace materials, Journal of the Faculty of Engineering and Architecture of Gazi University, 32 (1), 293-301, 2017.

14. Toktaş G., Toktaş A., Gülsün K., Effect of matrix structure and boriding time on the wear behaviour of $\mathrm{Cu}$ Ni-Mo alloyed ductile iron, Journal of the Faculty of Engineering and Architecture of Gazi University, 32 (2), 449-457, 2017.

15. Kuş A., Motorcu A.R., Estimation of the optimum cutting parameters for surface roughness in wire electrical discharge machining of nickel based waspaloy using Taguchi method, Journal of the Faculty of Engineering and Architecture of Gazi University, 32 (1), 195-204, 2017.

16. Göv K., Investigation of the effects of the dissolved oxygen in the coolant on the hole geometries drilled by electro erosion, Journal of the Faculty of Engineering and Architecture of Gazi University, 31 (2), 231-239, 2016.

17. Gülcan O., Uslan İ., Usta Y., Çoğun C., Effect of use of $\mathrm{Cu}-\mathrm{Cr} \mathrm{P} / \mathrm{M}$ electrodes on machining performance of electric discharge machining, Journal of the Faculty of Engineering and Architecture of Gazi University, 30 (3), 381-394, 2015.

18. Ünal H., Yetgin S.H., The investigation of tribological performance of polyamide 6 polymer and polyamide 6/wax blend against themselves, Journal of the Faculty of Engineering and Architecture of Gazi University, 31 (2), 457-463, 2016.

19. Blau P.J., Fifty years of research on the wear of metals, Tribol. Int., 30 (5), 321-331, 1997.

20. Kangasrääsiö J. and Hemming B., Calibration of a flatbed scanner for traceable paper area measurement", Meas. Sci. Technol., 20 (10), 1-4, 2009.

21. Ruff A.W., Ives L.K., Measurement of solid particle velocity in erosive wear", Wear, 35 (1), 195-199, 1975.

22. Avcu E., Fidan S., Bora M.Ö., Çoban O., Taşkıran İ., Sinmazçelik T., Solid particle erosive wear behavior of glass mat reinforced PPS composites: Influence of erodent particle size, pressure, particle impingement angle, and velocity, Adv. in Polymer Tehnol., 32 (S1), E386-E398, 2013. 
